\title{
A comparative study of family structure and health status in Ondo State, South west, Nigeria
}

\author{
Bello C.B. ${ }^{1,2}$, Irinoye O.O. ${ }^{2}$ and *Akpor O.A. ${ }^{1}$
}

\begin{abstract}
Objectives: The main aim of the study was to explore the influence of family functioning on the health status of two-parent and one-parent families based on the Family System Theory.
\end{abstract}

Methods: The study employed a descriptive cross-sectional comparative design. An adopted intervieweradministered questionnaire which was administered to 250 one-parent families and 250 two-parent families was used. Family functioning was measured using general functioning scale of family assessment device while BMI and blood pressures measures were used to determine parents' health status.

Results: Findings showed a statistically significant association between family structure and family functioning $(\mathrm{t}(1332)=13.763, \mathrm{p}<0.05)$, two-parent families had higher family functioning pattern with mean score of $2.80 \pm 0.34$ compared with one-parent family with mean score of $2.50 \pm 0.51$. Also, higher number of one-parent mothers had normal BMI (49\%) compared to two-parent mothers (37\%), higher number of one-parent mothers also had normal blood pressure (44.1\%) compared to two-parent mothers $(42.4 \%)$. Also, higher number of one-parent fathers had normal BMI scores $(43.5 \%)$ compared to twoparent fathers $(40.4 \%)$.

Conclusion: It is paramount for community health care professionals especially community health nurses to engage more in family focused intervention such as improving family health behavior as a tool for meeting family health and health care support needs.

Keywords: Family functioning, health status, one-parent, two-parent

*Corresponding author

Akpor O.A.

http://orcid.org/0000-0002-8005-0037

Email: akporoa@abuad.edu.ng

${ }^{1}$ Department of Nursing, College of Medicine and Health Sciences, Afe Babalola University Ado-Ekiti, Nigeria

${ }^{2}$ Department of Nursing Science, College of Health Sciences, Obafemi Awolowo University, Ile-Ife, Nigeria

Research Journal of Health Sciences subscribed to terms and conditions of Open Access publication. Articles are distributed under the terms of Creative Commons Licence (CC BY-NC-ND 4.0). (http://creativecommons.org/licences/by-nc-nd/4.0).

http://dx.doi.org/10.4314/rejhs.v5i4.7 


\title{
Une étude comparative de la structure familiale et de l'état de santé dans l'État d'Ondo, Sud-Ouest, Nigéria
}

\author{
Bello C.B. ${ }^{1,2}$, Irinoye O.O. ${ }^{2}$ and *Akpor O.A. ${ }^{1}$
}

\section{Resume}

Objectifs: Le principal objectif de l'étude était d'explorer l'influence du fonctionnement de la famille sur l'état de santé des familles biparentales et monoparentales en se basant sur la théorie de la famille.

Méthodes: L'étude a utilisé un modèle comparatif transversal descriptif. Un questionnaire administré par l'intervieweur, qui a été administré à 250 familles monoparentales et à 250 familles biparentales, a été utilisé. Le fonctionnement de la famille a été mesuré à l'aide de l'échelle de fonctionnement générale du dispositif d'évaluation de la famille, tandis que des mesures de l'IMC et de la tension artérielle ont été utilisées pour déterminer l'état de santé des parents.

Résultats: Les résultats ont montré une association statistiquement significative entre la structure familiale et le fonctionnement familial $(\mathrm{t}(1332)=13.763, \mathrm{p}<0.05)$, les familles biparentales avaient un mode de fonctionnement familial supérieur avec un score moyen de $2.80 \pm 0.34$ par rapport aux familles monoparentales. score moyen de 2,50 $\pm 0,51$. De plus, un nombre plus élevé de mères monoparentales avaient un IMC normal (49\%) que les mères biparentales $(37 \%)$, un plus grand nombre de mères monoparentales avaient également une pression artérielle normale $(44,1 \%)$ que les mères biparentales ( $42,4 \%)$. De plus, le nombre de pères monoparentaux était plus élevé $(43,5 \%)$ que chez les pères biparentaux $(40,4 \%)$.

Conclusion: Il est primordial que les professionnels de la santé communautaire, en particulier les infirmières en santé communautaire, s'investissent davantage dans des interventions axées sur la famille, comme l'amélioration du comportement familial en matière de santé familiale et de soutien de la santé.

Mots-clés: Fonctionnement familial, état de santé, monoparental, biparental

*Correspondance auteur

Akpor O.A.

http://orcid.org/0000-0002-8005-0037

Email:akporoa@abuad.edu.ng

${ }^{1}$ Department of Nursing, College of Medicine and Health Sciences, Afe Babalola University Ado-Ekiti, Nigeria

${ }^{2}$ Department of Nursing Science, College of Health Sciences, Obafemi Awolowo University, Ile-Ife, Nigeria

Research Journal of Health Sciences subscribed to terms and conditions of Open Access publication. Articles are distributed under the terms of Creative Commons Licence (CC BY-NC-ND 4.0). (http://creativecommons.org/licences/by-nc-nd/4.0)

http://dx.doi.org/10.4314/rejhs.v5i4.7 


\section{INTRODUCTION}

According to McLanahan (1), health and well-being of individuals and populations is drawn from a combined action and interactions variety of factors that are personal, social, economic and environmental in nature. Family functioning refers to the structural/organizational characteristics and the interpersonal interactions of the family group such as problem solving, communication, roles, adaptability, warmth/closeness, and behavior control $(2,3,4)$. Family structure as well as its composition affects health behaviors and outcomes (2,3). Currently, there is diversity of family structures which vary differently from the traditional two-parent family. Interactions that occur within the family are complementary that is, each family member is influential and being influenced by the actions of other family members $(5,6)$. Families in every society have basic functions that are performed in different ways. When families fail to provide any of these functions over time, it may yield behavior that modify both children and adults. The extent to which a family functions as well as its ability to solve problems and assist members to attain their potential appreciably affects the individual's health status in the family $(7,8,9)$.

A common expression of family is the nuclear family which is also known as two-parent family. One-parent family is a form of broken family as it is not structurally intact and this might be due to various reasons such as death of a parent, divorce, separation, in which case, the family was never completed $(2,10)$. There is dearth of information on the statistics of single parenthood in Nigeria. Adelani and Ogunbanwo (11), and Adelani et al. (12) confirmed the fast growing of single parent family pattern in Nigeria, communal clashes; insurgency and terrorism in some parts of Nigeria and increase incidence of rape has contributed to reported increase in the number of single parents and orphans.

The prevalence of single parenting is on the increase due to various factor such as having a child out of wedlock including many teenagers, divorce cases and families separated due to migrant labor arrangement $(2,13)$. Wagner et. al. (14) mentioned a relationship between family structure and family functioning. Effective families functioning results in enhanced overall health and well-being of family members when compared to families who functions poorly. Disadvantaged family functioning can expose its members to poor nutrition, increased risk of being overweight which can predispose family members to other health-related problems $(15,16)$. It is assumed that there are differences in family routines and practices especially in the area of diet and physical activity based on its structure.

Previous studies have reported that life as single parent can be stressful for both the child and the parent as single parent families are confronted with the challenges of reduced financial resources, taking up new roles and responsibilities, putting in place new patterns of interaction within family and reorganization of routines and schedules $(16,17,18)$. These conditions are not conducive to one's health, because by functioning as both mother and father, single parents are faced with unnecessary stress, as they struggle to make provision for their children they may ignore their own needs, which eventually affect their physical and mental health $(19,20)$. There is dearth of empirical studies in Nigeria on functioning and health of families in relation to their structure. This study was therefore aimed at exploring the influence of family functioning on the health status of twoparent and one-parent families based on the Family System Theory in Ondo State, Nigeria.

\section{Theoretical Application}

The theoretical framework for this study is the Family System Theory (21) that was developed by Dr Murray Bowen. According to Kerr (21), there are anticipated patterns of interaction that occur in a family system and this help to maintain the family's equilibrium as well as provide hints on how each member should function. The theory also focuses on the bigpicture pattern of a family system instead of a narrower view of what causes difficulties for an individual in the family.

The Family System Theory is a theory of human behaviour that views the family as an emotional unit and uses systems thinking to describe the intricate interactions in the family unit. It is opined that it is normal for members of a family to be passionately connected emotionally. There are eight concepts addressed by this theory and these includes triangles, differentiation of self, nuclear family emotional system, family emotional process, multigenerational transmission process, emotional cut-off, sibling position and societal emotional process. In this study, only four of the concept will be applied.

- Differentiation of self is the ability to be in emotional contact with others within the 
family and yet still autonomous in one's own emotional functioning. Each individual member of the family becomes more of a self in his or her family system through a gradual process of learning which culminate in action. In relation to family functioning and health status, positive happening within the family such as adequate parental care and supportive spouse relationship can promote positive change in each member of the family thereby improving family functioning and consequently the general health status of the family as a whole.

- Family emotional system is an automatic process that is common to every member of a family. According to the theory (21), the existence of a family emotional field is the result of an emotionally driven relationship process that is usually present in all types of families. In relation to this study, families can have an unfathomable effect on individual member's thought, feelings and actions. In both one-parent and two-parent families, it is expected that each member will solicit other's attention, approval, as well as support and likewise react to each other's needs and expectation and upsets.

- Emotional cut-off refers to the phenomenon of emotional distancing. It is a form of internal mechanism of physical distancing, and it is seen as a natural process. In relation to this study, a change in a family member's functioning or negative health statuses especially that of a parent will predictably followed by reciprocal changes in the functioning of other members, and subsequently affect the general well-being of other members of the family.

- In nuclear family emotional system, the purpose of emotional interdependence of family members is to promote the cohesiveness, as well as the cooperation that the system works in individual family. The social system will reveal new and more effective options for providing health support and treatment to solving problems in all areas of the family functioning.

It is expected of families to protect, shelter, and feed their members. Heightened tension within the family such as emotional stress, illhealth, financial incapacity may leads to problems that will consequently affect the family unity as well as their teamwork thereby affecting the family normal functioning and ultimately their health status. For example, when a member (especially in a one-parent family) assumes too many responsibilities, such a member can absorb system anxiety thus making the family member vulnerable to problems such as depression, alcoholism as well as physical illness. Hence, it is imperative for HCPs to view family as a whole in their care and support rather than focussing only on the client alone.

\section{MATERIALS AND METHODS}

The design of the study was crosssectional descriptive with a quantitative. Four local government areas (LGA) were selected from Ondo State in Nigeria, the State consists of three senatorial districts and each senatorial district has six local government areas.

The simple random sampling technique was used to select four LGAs from the eighteen in the State with one-third of the wards in each of the four selected LGA. The inclusion criteria for the study were: two-parent families with at least one child, one-parent families, which can be either the father or mother with at least one child and willingness to participate in the study. The sample size was determined using sample size formula for comparing proportions and means of independent groups. Sample size was 250 families each for the two groups.

Data were collected using an interviewer -administered questionnaire with the English or Yoruba version of the instrument. Items on the questionnaire comprised of participants' demographic data and items assessing family functioning. Family functioning was measured using general functioning scale of the family assessment device while BMI and blood pressures measures were used to determine health status of parents. Family functioning of was assessed through self-reported items drawn from the general functioning scale of the Family Assessment Device (FAD) which was taken from the McMaster Family Assessment Device (4).

The validity of instruments was ascertained through a critical review of the interviewer-administered questionnaire to ensure all necessary variables were included. The questionnaire used a Likert scale of 4 points: strongly disagree, disagree, agree and strongly agree representing 1,2,3 and 4, respectively. All statements were converted to the positive form before the values were summed and higher mean scores representing higher family functioning. All measurements were completed following standardized procedures (22). 
Two research assistants were recruited and trained, the first author and research assistants contacted respondents through home visits at pre-arranged time; revisits were made where necessary in order to get family members. The father and mother were interviewed in twoparent families whereas the father or mother in one-parent families. Further briefing on the study aims and objectives was done prior to the participants completing and signing the consent forms. Interviews with each member of the family were conducted privately and individual information was not shared.

The approval for the study was sought and granted by the Ethical and Research Committee of the Department of Nursing Science, Obafemi Awolowo University Nigeria. Further approvals were granted by the community leaders in each LGA. The purpose of this study was explained to each participant and both verbal and written consent were obtained from respondents prior to data collection. Confidentiality was ensured by using codes for each questionnaire and completed questionnaires were kept in locked drawers to ensure limited access to information.

Data entering was done with the aid of Statistical Package for Social Sciences (SPSS) version 17.0. Both descriptive and inferential statistics were used for data analysis. BMI and blood pressure were calculated using frequency and percentage. Differences in the percentage of BMI and blood pressure were shown using bar charts.

\section{RESULTS}

The demographic data of the participants from two-parent and one-parent families are summarized in Table 1. From the two-parent families, there were 250 men and women each, while from the one-parent families, there were 39 $(15.6 \%)$ men and $211(84.4 \%)$ women. The mean age of parents was 45 years while the mean family income was N74, 000. Majority of participants in both families had formal education.

\section{Data on family functioning}

The breakdown of information on all the six domains of family functioning is summarized in Table 2. An independent sample t-test comparing the mean score of two-parent and oneparent families was used. Two-parent family scored higher than one-parent family in all the domains of family functioning and are all statistically significant except in behavior control where two-parent scored less $(2.49 \pm 0.29)$ than one parent $(2.50 \pm 0.24)$ family which was not significant. The result of the total mean score of all the domains also showed that two-parent families had higher family functioning pattern with mean score of $2.87 \pm 0.34$ compared with one-parent family with mean score $2.55 \pm 0.50$. This showed a statistically significant association between family structure and family functioning $(t(1332)=13.763, p<0.05)$, the result showed that two-parent family has higher family functioning than one-parent family.

\section{BMI classification}

The BMI classification showed that $49.3 \%$ mothers from one-parent family had normal BMI, while $50.7 \%$ had abnormal BMI that ranges between underweight $(1.4 \%)$, preobese $(31.8 \%)$ and obese $(17.5 \%)$, whereas only $37.2 \%$ mothers from two-parent family had normal BMI, and $62.8 \%$ had abnormal BMI as follows, underweight $(0.8 \%)$, pre-obese $(40.4 \%)$ and obese $(21.6 \%)$. This result showed that oneparent mothers are healthier than two-parent mothers (Figure 1).

A total of $43.5 \%$ fathers from one-parent family had normal BMI, while $56.5 \%$ had abnormal BMI that ranged between pre-obese $(46.2 \%)$ and obese $(10.3 \%)$. Only $40.4 \%$ fathers from two-parent family had normal BMI while $59.6 \%$ had abnormal BMI (Figure 2).

\section{Blood pressure classification}

Figure 3 showed the blood pressure classification of mothers from two-parent and one-parent families. Result showed that $44.1 \%$ mothers from one-parent family had normal BP while $55.9 \%$ has abnormal $\mathrm{BP}$ that ranges from hypotension (4.3\%), pre-hypertension $(28.4 \%)$, stage 1 hypertension (20.4\%) and stage2 hypertension (2.8\%). While $42.4 \%$ of two-parent mothers had normal BP whereas 57.6\% had abnormal BP that ranges from hypotension $(2.4 \%)$, pre-hypertension $(34.0 \%)$, stage 1 hypertension $(18.0 \%)$, stage 2 hypertension $(2.4 \%)$ and hypertensive emergency $(0.8 \%)$.

A total of that $35.9 \%$ fathers from oneparent family had normal BP while $64.1 \%$ had abnormal BP that ranges from pre-hypertension (33.3\%), stage1 hypertension (23.1\%) and stage 2 hypertension $(7.7 \%$ ) while $32.8 \%$ fathers from two-parent family had normal BP, and the remaining $67.2 \%$ had abnormal BP (Figure 4 ).

Family functioning and health status score

As shown in Figure 5 and 6, the family 
functioning of one parent families was lower than the two-parent families. Among the one- parent families with high health status, less than $60 \%$ had high family functioning pattern. More than $60 \%$ of two-parent families with high health status also had high family functioning.

\section{DISCUSSION}

As shown in the study, parents from both families have similar demographic characteristics. The average monthly family income of one-parent families is lower than that of two-parent families. This is consistent with findings from many studies that clearly link single parenthood and poverty, because oneparent have more financial burden than twoparent families (23).

According to Berman and Snyder (2), there are reduced numbers of single fathers despite the increase in single parenthood. This is consistent with the finding of this study as there are few $(15.6 \%)$ single parent fathers when compared to single parent mothers. Casper, Fields and Casper (24), Berman and Snyder (2) explained that the reason is that mothers are often the one granted the custody of children while fathers usually cohabit or remarry early, unlike their female counterpart.

This study revealed higher family functioning in two-parent families than oneparent families; this is consistent with findings from previous studies $(9,16,17)$ revealed the strong association between family structure and family functioning indicating a higher level of family functioning in two-parent family structure. Likewise Peatling (16) stated that lower levels of family functioning in single parents households maybe sue to various factors such as low income, welfare status, low maternal education, as well as maternal depression.

The findings on the effect of family structure on parental behavioral control between the two types of families was not concluded in this study but previous researchers $(25,26)$ revealed in their studies that the level of parental monitoring was lower in single-parent families than in two-parent families. Equally, Shek (27) studied parental behavioral control in five dimensions and revealed that parental knowledge, expectation, monitoring, discipline, and demandingness were weaker in single parent families than two-parent families. Further result showed that more one-parent mothers have normal BMI and normal blood pressure compared with two-parent mothers hence; one- parent mothers are healthier than two-parent mothers but there are dearth of literature in respect of BMI and blood pressure of mothers. Some studies (28) make references to mothers when comparing health of families in relation to their structure. In another study by Westin and Westerling (29), it was revealed that both single fathers and single mothers reported poorer health status than two-parent fathers and mothers, although, single fathers usually visit physicians more frequently than two-parent fathers but conversely, whereas single mothers were reported to often refrain from seeing a physician regardless of a need for medical attention when compared with two-parent mothers.

\section{CONCLUSION}

Findings from this study have shown that two-parent families have higher level of family functioning than one-parent families and likewise, fathers and mothers from one-parent families are healthier than two-parent families. It is paramount for nurses to engage more in family focused intervention such as improving family health behavior as a tool for meeting family needs. Nurses must also focus on the clients' family when assessing, diagnosing, planning, implementing and evaluating nursing care. Clients care must be taken beyond health facilities; further care at home in form of home visits will give some level of family support and enhance family functioning thereby promoting healthy behavior.

Also as shown in the study, there is a need for family focused public health intervention in the prevention of chronic diseases and necessary advocacy for policy development with regards to family support must be put in place so as to improve the socio-economic status of families especially one-parent families.

Acknowledgments: The authors are grateful to the participants and relevant authorities granted permission to conduct the research.

Conflict of interest: The author(s) declared no potential conflicts of interest with respect to the research, authorship and/or publication of this article.

\section{Authors' contributions}

CBB worked with OOI to conceptualize the study. CBB collected and analysed data, was involved in literature search and reported the findings. OOI checked the literature and the data, 
proof read the findings and supervise the research process. OAA was involved in literature search and updating, data analysis and finalised the manuscript. All authors read and approved the final manuscript.

\section{REFERENCES}

1. McLanahan S. Children in Fragile Families. Working paper \#09-16-FF, Center for Research on Child Wellbeing, 2009, Princeton University

2. Berman, A \& Snyder, S. Kozier and Erb's Fundamental of Nursing, Conceps, Process and Practice, New Jesey: Pearson, 2012.

3. Marks J, Bun LC \& McHale SM. Family Patterns of Gender Role Attitude. HHS Public Access, 2012, 61(3), 221-234.

4. Miller IW, Epstein NB, Bishop DS \& Keitner GI. The McMaster Family Assessment Device: Reliability and validity. Journal of Marital and Family Therapy, 1985, 11,345-356.

5. Healthy Chidren.org. Roles within the family. Family Life, 2015, 1-2.

6. Whitchurch GG \& Constantine LL. Systems theory. In: Boss PG, Doherty WJ, LaRossa R, Schumm WR, Steinmetz SK, editors. Sourcebook on family theories and methods: A contextual approach. New York: Plenum Press, 1993.

7. Agulanna GG. Family structure and prevalence of behavioral problems among Nigerian adolescents. The Counselor, 1999, 17(1): 154154.

8. Allender JA \& Spradley BW. Community Heath Nursing: Concept and Practice, China: Lippincott, 2005.

9. Anderson J. The impact of family structure on the health of children: effects of divorce. The Linacare Quarterly, 2014, 81 (4): 378-387.

10. Conkline J. Introduction to Criminology. New York: Macmillan, 1996.

11. Adelani T \& Ogunbanwo B. Emergence of Single Parenthood in Nigeria and its implication to child rearing. Continental J. Nursing Science, 2008, 1: 9-12.

12. Adelani T, Afolayan AW, Sanusi JA, Olubiyi RA, Imam K, Ibraheem A et al. Emergence of single parenthood in Ibadan, Nigeria and its implication to child rearing. International Journal of Research in Applied Natural and Social Sciences, 2015,3 (8): 71-80.

13. Kim HK, Viner-Brown SI \& Garcia J. Children's Mental Health and Family Functioning in Rhode Island. Pediatrics, 2007, 119 (Suppl 1):S22-8.

14. Wagner KD, Ritt-Olson A, Chou C, Pokhrel P, Duan L, Baezconde-Garbanati L, et al. (2010) Associations between family structure, family functioning, and substance use among Hispanic/Latino adolescents. Psycho Addict Behavior, 2010, 24(1): 98-108.

15. Rhee KE. Childhood Overweight and the Relationship between Parents Behaviors,
Parenting Style and Family Functioning. The ANNALS of the American Academy of Political and Social Science, 2008, 615: 11-37.

16. Peatling $\mathrm{S}$. Children of single parents disadvantaged for longer. Federal Politics, 2013, 1-4.

17. Yeung JWK \& Chan YC. Family functioning of Chinese families on an impoverished neighborhood in Hong Kong. Psychological Reports, 2010, 107(3): 740-748.

18. Li X, Zou H, Liu Y \& Zhou Q. The Relationships of Family Socioeconomic Status Parent-Adolescent Conflict, and Filial Piety to Adolescents' Family Functioning in Mainland China. Journal of child and family study, 2014, 23 (1): 29-38.

19. Agulanna GG. Family structure and prevalence of behavioral problems among Nigerian adolescents. The Counselor, 1999, 17(1): 154154.

20. Sierau S, Lehmann E \& Jungmann T. Fathers in disadvantaged families. Family Science, 2011, 2 (2): 1-3.

21. Kerr ME. One Family's Story: A Primer on Bowen Theory. The Bowen Center for the Study of the Family, 2000.

22. Gibson LY, Byrne SM, Davis EA, Blair E, Jacoby P \& Zubrick SR. The role of family and maternal factors in childhood obesity. Medical Journal of

Australia, 2007, 186(11):591-596.

23. Conger $\mathrm{R}$, Conger $\mathrm{K} \&$ Martin $\mathrm{MJ}$. Socioeconomic status, family processes and individual development. HHS Public Access, 2011, 72 (3): 685-704.

24. Casper J, Fields LM \& Casper. America's Families and Living Arrangements: Center for Marriage and Families. Family Structure and Children Educational Outcomes. New York: Center for Marriage and Families 2005.

25. Florsheim P, Tolan P \& Gorman-Smith D. Family relationships, parenting practices, the availability of male family members, and the behavior of inner-city boys in single-mother and two-parent families. Child Dev, 1998, 69 (5):1437-1467.

26. Pettit GS, Laird RD, Dodge KA, Bates JE \& Criss MM. Antecedents and behavior-problem outcomes of parental monitoring and psychological control in early adolescence. Child Dev, 2001, 72 (2): 583-98.

27. Shek DTL. Perceived parental control processes, parent-child relational qualities, and adolescent psychological well-being in intact and non-intact families: longitudinal findings in the Chinese culture. J Divorce Remarriage, 2008, 49 (1-2): 171-187.

28. Bramlet MD \& Blumberg SJ. Family Structure and Children's Physical and Mental Health. New York, Health Aff, 2007, 26 (2): 549-558.

29. Westin M \& Westerling R. Health and healthcare utilization among single mothers and single fathers in Sweden. Scand J Public Health, 2006, 34: 182-189. 
Table 1: Demographic characteristic of respondents $(n=750)$

\begin{tabular}{|c|c|c|c|c|}
\hline \multirow[t]{2}{*}{ Characteristics } & \multicolumn{2}{|c|}{$\begin{array}{l}\text { Two-parent families } \\
(\mathrm{n}=500(250 \text { couples }))\end{array}$} & \multicolumn{2}{|c|}{$\begin{array}{l}\text { One-parent families } \\
(\mathrm{n}=250)\end{array}$} \\
\hline & Frequency & $\%$ & Frequency & $\%$ \\
\hline \multicolumn{5}{|l|}{ Gender } \\
\hline Male & 250 & 50.0 & 39 & 15.6 \\
\hline Female & 250 & 50.0 & 211 & 84.4 \\
\hline \multicolumn{5}{|l|}{ Age in years } \\
\hline $20-40$ & 216 & 43.2 & 100 & 40.0 \\
\hline $41-60$ & 236 & 47.2 & 48.0 & 48.0 \\
\hline Above 60 & 48 & 9.6 & 30 & 12.0 \\
\hline \multicolumn{5}{|l|}{ Educational status } \\
\hline No formal education & 30 & 6.0 & 13 & 5.2 \\
\hline Primary School Completed & 110 & 22.0 & 58 & 23.2 \\
\hline Secondary School Completed & 240 & 48.0 & 105 & 42.0 \\
\hline Tertiary Education & 120 & 24.0 & 74 & 29.6 \\
\hline \multicolumn{5}{|l|}{ Family monthly income } \\
\hline Up to $\mathrm{N} 20000$ & 50 & 20.0 & 94 & 37.6 \\
\hline N21000-N50000 & 62 & 24.8 & 76 & 30.4 \\
\hline N51000-N100000 & 100 & 40.0 & 75 & 30.0 \\
\hline Above N100000 & 38 & 15.2 & 5 & 2.0 \\
\hline
\end{tabular}

Table 2: Means score, standard deviation, $t-$ value and significant difference of Family Functioning Pattern of one-parent $(n=250)$ and two-parent families $(n=500)$

\begin{tabular}{|c|c|c|c|c|c|c|}
\hline $\mathrm{S} / \mathrm{N}$ & $\begin{array}{ll}\text { Family functioning } \\
\text { domains }\end{array}$ & $\begin{array}{l}\text { Family structure } \\
\text { One parent } n=250 \\
\text { Two-parents } n=500\end{array}$ & Mean score & $\begin{array}{l}\text { Standard } \\
\text { deviation }\end{array}$ & t- value & $\begin{array}{l}\text { Significance } \\
\text { P- value }\end{array}$ \\
\hline \multirow[t]{2}{*}{1} & \multirow[t]{2}{*}{ Problem solving } & One-parent & 2.5 & 0.69 & 12.686 & 0.0001 \\
\hline & & Two-parent & 3.0 & 0.50 & & (S) \\
\hline \multirow[t]{2}{*}{2} & \multirow[t]{2}{*}{ Communication } & One-parent & 2.50 & 0.72 & -12.441 & 0.0001 \\
\hline & & Two-parent & 2.92 & 0.52 & & (S) \\
\hline \multirow[t]{2}{*}{3} & \multirow[t]{2}{*}{ Role } & One-parent & 2.54 & 0.67 & -10.878 & 0.0001 \\
\hline & & Two-parent & 2.90 & 0.52 & & (S) \\
\hline \multirow[t]{2}{*}{4} & \multirow{2}{*}{$\begin{array}{l}\text { Affective } \\
\text { responsiveness }\end{array}$} & One-parent & 2.58 & 0.66 & -11.815 & 0.0001 \\
\hline & & Two-parent & 2.97 & 0.51 & & (S) \\
\hline \multirow[t]{2}{*}{5} & \multirow[t]{2}{*}{ Affective involvement } & One-parent & 2.59 & 0.77 & -11.364 & 0.0001 \\
\hline & & Two-parent & 2.99 & 0.51 & & $(\mathrm{~S})$ \\
\hline \multirow[t]{2}{*}{6} & \multirow[t]{2}{*}{ Behavior control } & One-parent & 2.50 & 0.24 & -0.991 & 0.322 \\
\hline & & Two-parent & 2.49 & 0.29 & & (NS) \\
\hline \multirow[t]{2}{*}{7} & Average & One-parent & 2.50 & 0.51 & -13.918 & 0.0001 \\
\hline & & Two-parent & 2.80 & 0.34 & & $(\mathrm{~S})$ \\
\hline
\end{tabular}




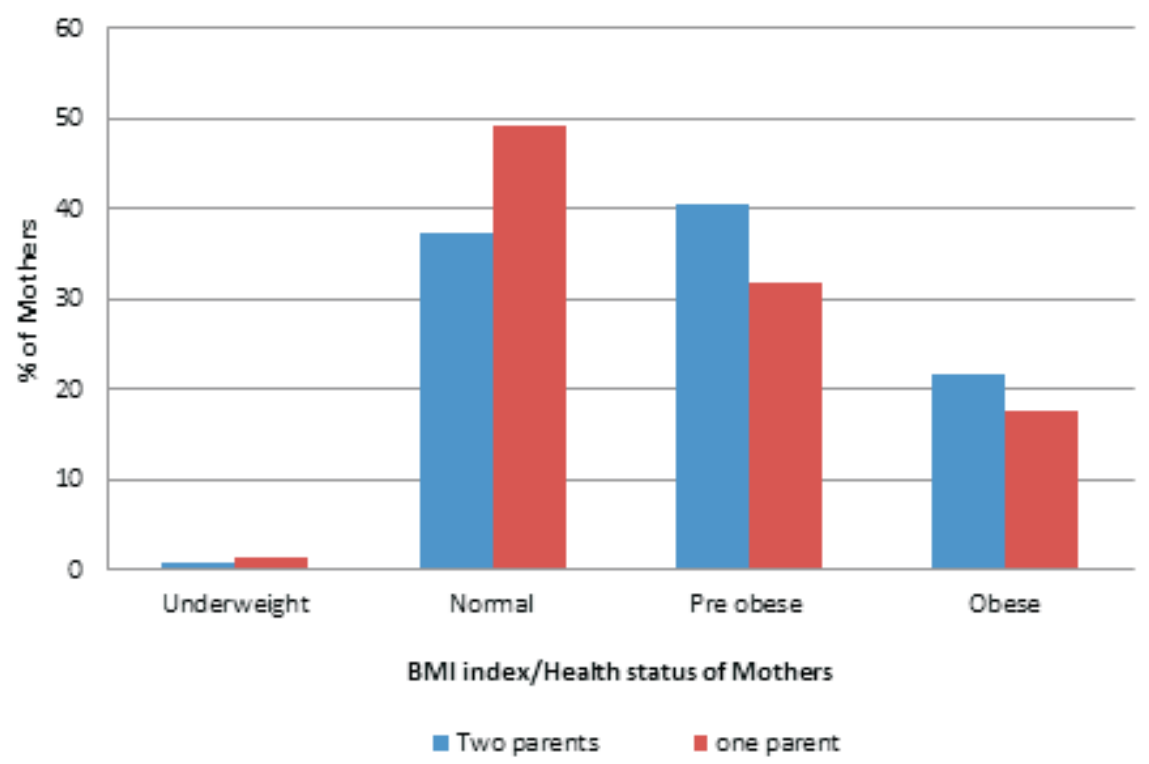

Figure 1: Basal Metabolic Index (BMI) of Mothers $(n=461)$

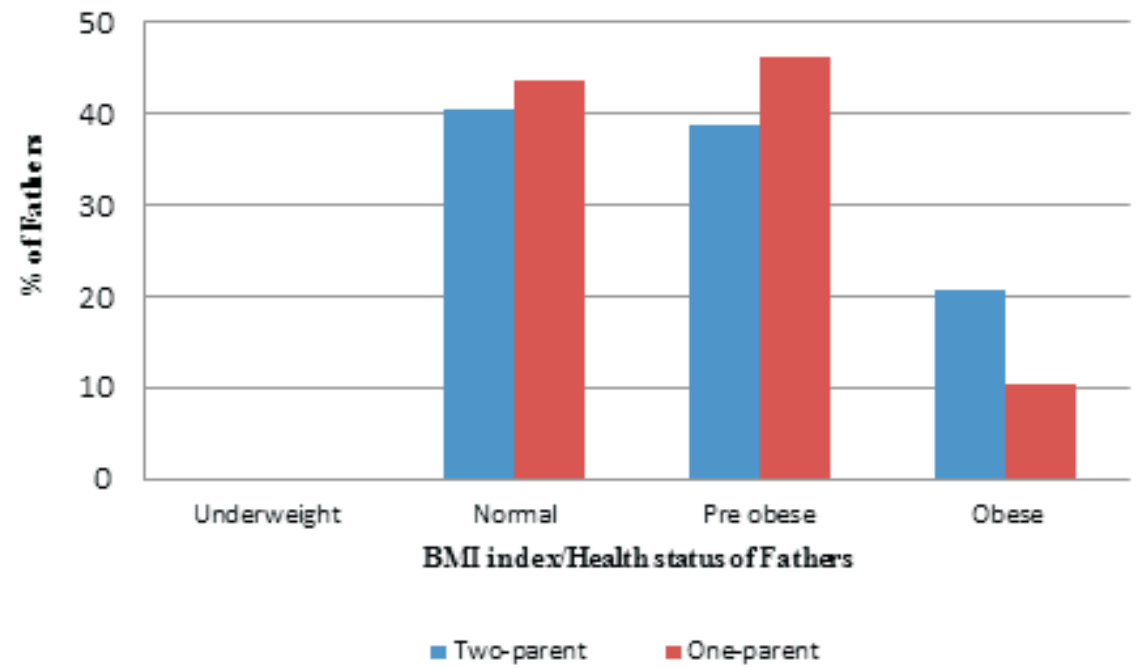

Figure 2: Basal metabolic index (BMI) of fathers $(n=289)$

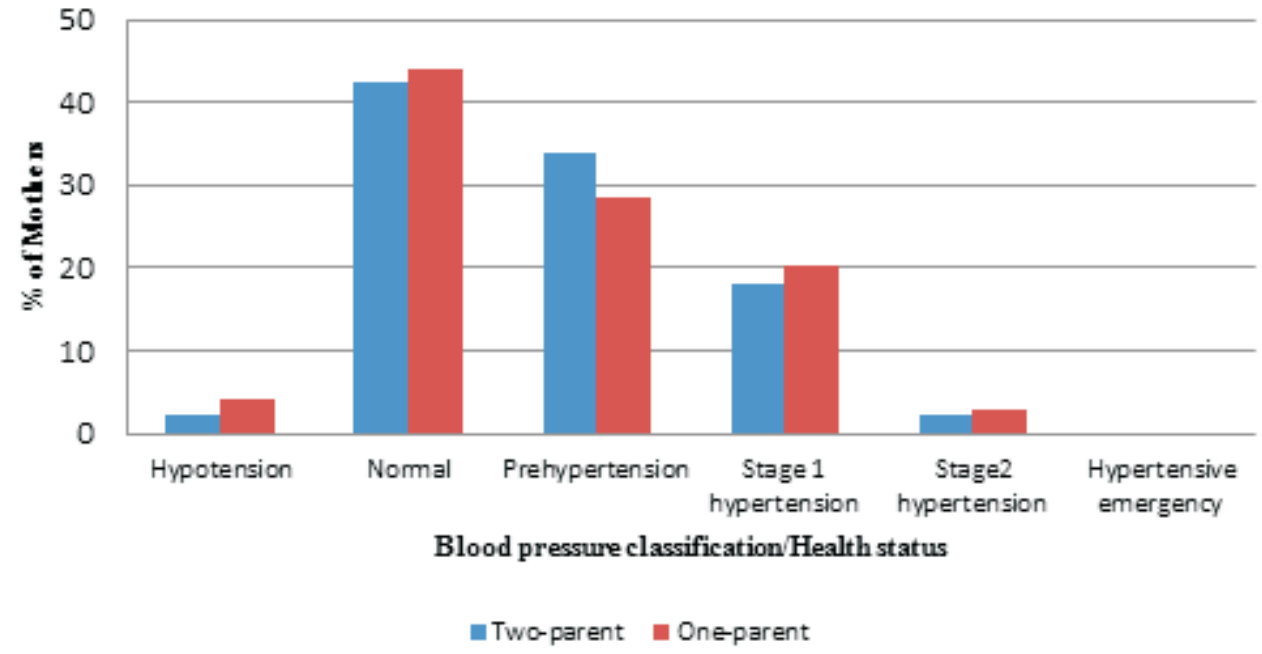

Figure 3: Blood pressure classification of mothers $(n=461)$ 


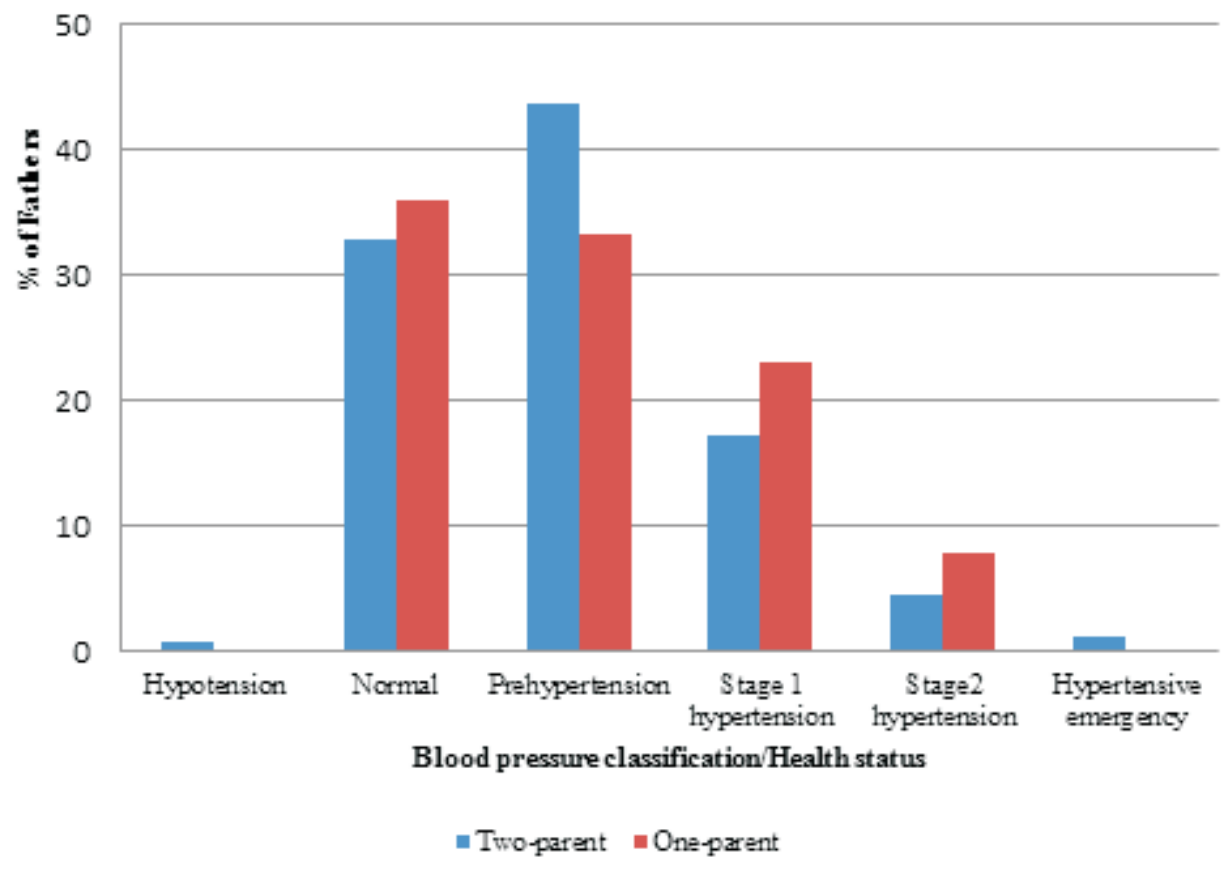

Figure 4: Blood pressure classification of fathers $(n=289)$

\section{Type of family=One parent}

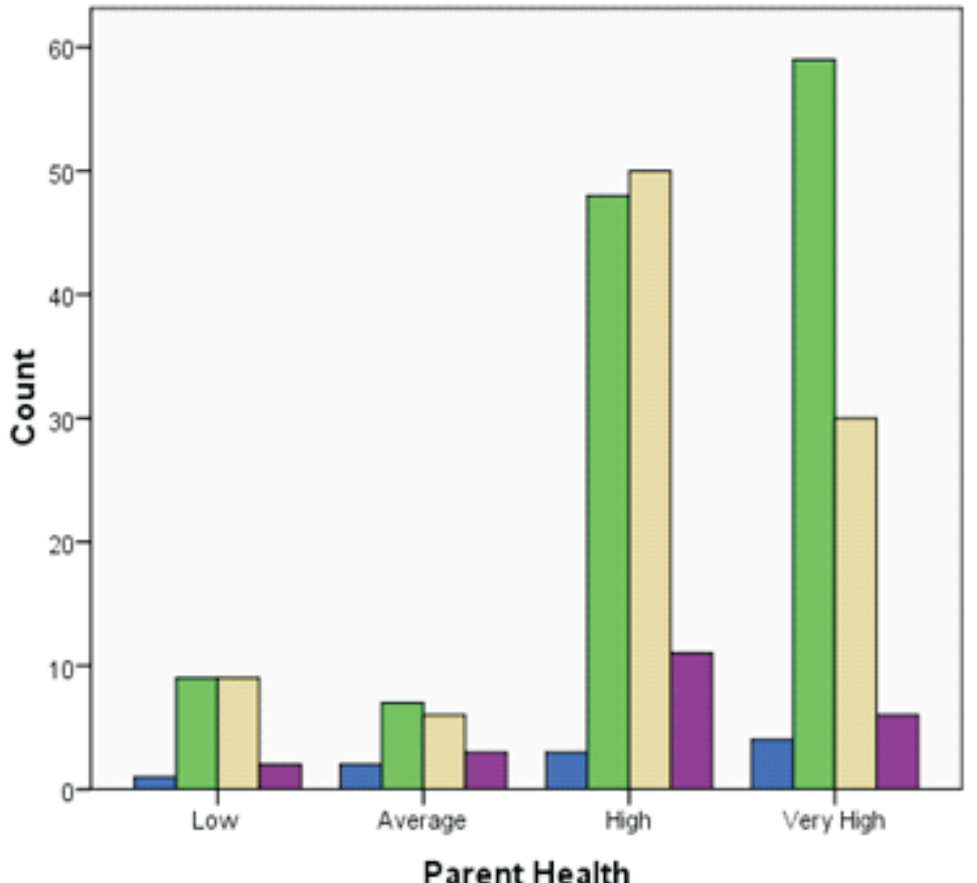

Fandy funcion

口Low

Average

口High

Wery High

Parent Health

Figure 4: Family functioning and health status of one-parent families $(n=250)$ 
Type of family=Two parents

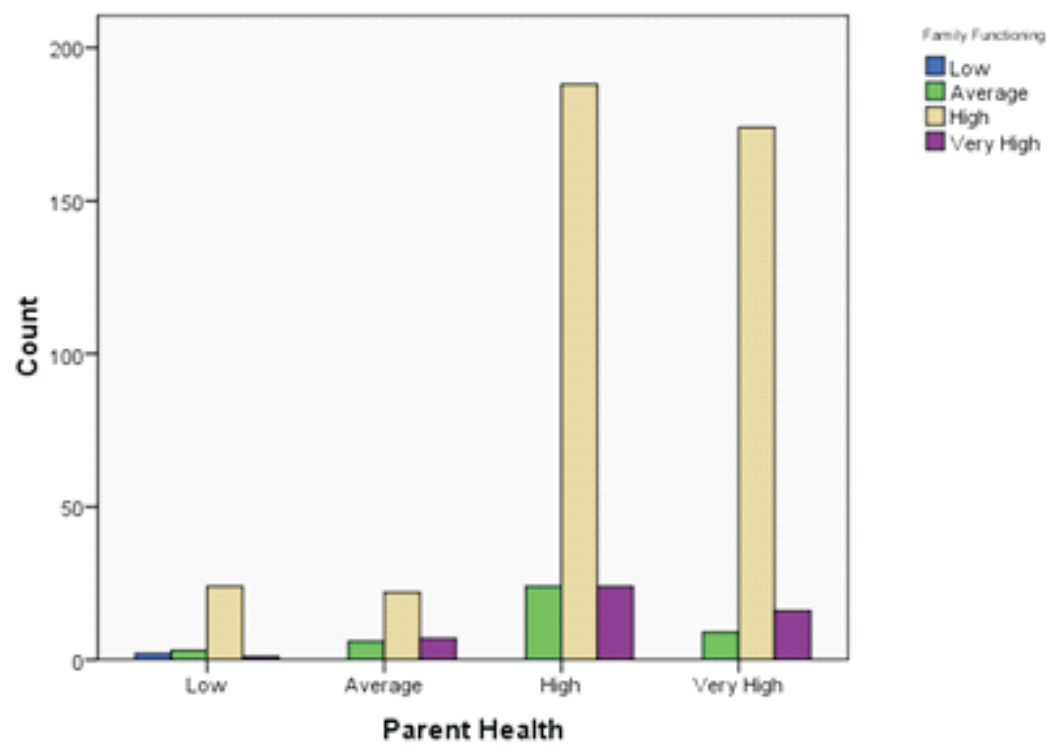

Figure 5: Family functioning and health status of two-parent families $(n=500)$ 